\title{
Böbrek hücreli karsinomda kemik metastazı
}

\section{Bone metastasis in renal cell carcinoma}

\author{
Volkan Gürkan ${ }^{1}$, Özgür Erdoğan²
}

\begin{abstract}
'Bezmialem Vakıf Üniversitesi Tıp Fakültesi, Ortopedi ve Travmatoloji Anabilim Dalı, İstanbul ${ }^{2}$ Haydarpaşa Numune Eğitim ve Araştırma Hastanesi, Ortopedi ve Travmatoloji Kliniği, İstanbul
\end{abstract}

\begin{abstract}
Böbrek hücreli karsinomlar (BHK) böbrek tübüllerinin epitelinden köken alan, bir grup kötü huylu tümördür. Bunlar, tüm yetişkin karsinomlarının \%3'ünü kapsar, böbreğin en sık görülen (\%90) kötü huylu tümörüdür ve beş yılık sağkalım oranı \%45'tir. Kemik metastazı ikinci en sık metastaz bölgesidir ve metastatik BHK'lerin \%30'unda kemik metastazı görülür. BHK kemikte en sık omurga, pelvis ve proksimal femura metastaz yapar. BHK'nin kemoterapi ve radyoterapiye dirençli ve immünoterapiye yanıtının sadece \%5-10 oranında olması, hedefe yönelik tedavilerin ortaya çıkmasına yol açmıştır. Tedavide ana hedef; sinir basısı, kırık ve hiperkalsemi gibi bulguların önlenmesi, ağrının hafifletilmesi ve yaşam kalitesinin artırılmasıdır. Metastatik BHK'de; ağrı, hiperkalsemi, hipertansiyon ve eritrositoz nedeniyle olgulara nefrektomi önerilmektedir. Eğer hastada patolojik kırık yoksa ve tek metastaz varsa, cerrahi sınırın temiz olduğu bir geniş rezeksiyon, daha uzun hayatta kalım süreleri elde edilmesini sağlayacaktır. Eğer kemikte çoklu metastaz varsa, cerrahi sadece; kırık riskini düşürmek, patolojik kırıkları tespit etmek, acil spinal dekompresyon ve spinal instabiliteyi azaltmak amacıyla yapılır.
\end{abstract}

Sonuç olarak; metastatik BHK insidansı, hedefe yönelik tedaviler sayesinde uzayan yaşam süreleri ile birlikte artmaktadır. Olguların \%85'inde "iskelet ilişkili olaylar" (skeletal related events -SRE) adı verilen semptomlar görülmektedir. Bu semptomlar, ekonomik yük oluşturmakta, yaşam kalitesini azaltmakta, morbidite ve mortalite oranlarını artırmaktadır. Bununla birlikte, tek metastazı olan bir BHK olgusunda, primer tümörün ve metastazın rezeksiyonunun daha uzun yaşam süresi sağlayabileceği unutulmamalıdır. Ayrıca, geniş lezyonlarda, progresif kemik destrüksiyonlarında, kırık beklentisinde, kontrol edilemeyen ağrı durumunda ve instabilite varlığında da palyatif olarak metastaz rezeksiyonu uygulanabilir.

Anahtar sözcükler: böbrek kanseri; kemik; metastaz
Renal cell carcinomas (RCC) are a group of malignant tumors originating from the epithelium of the renal tubules. This group covers $3 \%$ of all adult carcinomas, the most common malignant tumor (90\%) of the kidney, and 5 -year survival rate is $45 \%$. Bone metastasis is the second most common metastasis site, and bone metastasis is seen in $30 \%$ of metastatic RCCs. In the bone, RCC most commonly metastasizes to the spine, pelvis, and proximal femur. The fact that RCC is resistant to chemotherapy and radiotherapy, and the response to immunotherapy alone can be achieved in only $5-10 \%$ of patients, has led to the emergence of targeted therapies. The main target in treatment is prevention of symptoms such as nerve compression, fracture and hypercalcemia, palliation of pain, and increasing the quality of life. Nephrectomy is recommended in patients with metastatic RCC due to pain, hypercalcemia, hypertension, and erythrocytosis. In the absence of pathological fracture, a wide resection with clear margins should be performed for a solitary metastasis. If there is multiple metastasis in the bone, surgery should be considered only to reduce the risk of fractures, to detect pathological fractures, emergent spinal decompression, and to reduce spinal instability.

In conclusion, the incidence of metastatic RCC increases with prolonged survival due to targeted therapies. Skeletal related events (SRE) and associated complications are seen in $85 \%$ of the cases. These symptoms cause economic burden, decrease quality of life, and increase morbidity and mortality rates. However, it should be kept in mind that resection of the primary tumor and solitary metastasis may lead to a longer life in the case of solitary metastasis. Besides, wide resection of a metastasis can be performed as a palliative treatment in large lesions, progressive bone destruction, uncontrolled pain, instability, and to prevent fractures.

Key words: bone; metastasis; renal cell carcinoma

- İletişim adresi: Op. Dr. Özgür Erdoğan, Tıbbiye Cad. No:40 Üsküdar, İstanbul Tel: 0506 - 2844804 e-posta: drozgurerdogan@gmail.com

- Geliş tarihi: 26 Ağustos 2019 Kabul tarihi: 1 Kasım 2019 
B öbrek hücreli karsinomlar (BHK), böbrek tübüllerinin epitelinden köken alan bir grup kötü huylu tümördür. Bunlar, tüm yetişkin karsinomlarının \%3'ünü kapsar. ${ }^{[1]}$ Böbreğin \%90 oranında en sık görülen kötü huylu tümörüdür ve beş yıllık sağkalım oranı \%45'tir. ${ }^{[2]}$ İnsidansı $60-70$ yaş arasında zirve yapar ve erkeklerde kadınlardan daha sık görülür. BHK'nin berrak hücreli, papiller ve kromofob olmak üzere üç alt tipi bulunmaktadır. Berrak hücreli tipi en sık görülen tiptir. BHK'li hastaların yaklaşık 1/3'ünde tanı anında, yarısında ise takip esnasında metastaz saptanmaktadır. Son yıllarda, ultrasonografi (US) ve bilgisayarlı tomografi (BT) tekniklerinin yaygınlaşmasıyla erken tanı mümkün olmuştur. Olguların büyük çoğunluğunda tanı, batın içi başka patolojileri araştırırken rastlantısal olarak konulmaktadır. ${ }^{[3]}$ Tedavi; erken evrede ve lokalize lezyonlarda, parsiyel ya da radikal nefrektomidir. Miyao ve ark. rezeksiyon sonrası rekürrens oranını \%10,521,6 arasında bildirmişlerdir. ${ }^{[4]}$ BHK, en sık akciğere metastaz yapar. Kemik metastazı ikinci en sık metastaz bölgesidir ve metastatik BHK'lerin \%30'unda kemik metastazı görülür. ${ }^{\left[{ }^{[]}\right.}$Sonrasında; sırasıyla, lenf nodu, karaciğer, adrenal bezler ve beyin metastazları bildirilmiştir. BHK'nin kemoterapi ve radyoterapiye dirençli olması ve immünoterapiye yanıtın ise sadece \%5-10 hastada elde edilebilmesi, hedefe yönelik tedavilerin ortaya çıkmasına yol açmıştır. Hedefe yönelik tedavide ise vasküler endoteliyal büyüme faktörü - tirozin kinaz inhibitörleri (VEGF-TKIs) ve mammalian target of rapamycin (mTOR) inhibitörleri kullanılır. Metastatik hastalıkta median hayatta kalma süresi sekiz ay olarak bildirilmiştir. Sitokin tedavisiyle bu süre 13 aya kadar uzamaktadır. ${ }^{[6]}$ Hedefe yönelik tedaviler ile hayatta kalım süreleri daha uzun olsa da, tam remisyon nadirdir. ilk yılda mortalite oranı $\% 50$, beş yıllık hayatta kalma oranı ise \%10'dur. ${ }^{[7]} \mathrm{BHK}$, cerrahi ya da medikal tedavi gerektiren ve literatürde "iskelet ilişkili olaylar" (skeletal related events -SRE) adıyla anılan bir grup semptom ile ilişkilidir. Woodward ve ark., kemik metastazlı hastalarda takip esnasında görülen ortalama SRE sayısını 2,4 olarak bildirmişlerdir. ${ }^{\left[{ }^{8]}\right.} \mathrm{BHK}$, kemikte en sık omurga, pelvis ve proksimal femura metastaz yapar. Ruatta ve ark., kemik metastazI $300 \mathrm{BHK}$ olgusunu inceledikleri çalışmalarında, 177 (\%59) spinal, 116 (\%39) sakrum ve 94 (\%31) uzun kemik metastazı bildirmişler; ayrıca, uzun kemik metastazlı olguların spinal ve sakrum metastazlı olgulara göre daha iyi prognoza sahip olduklarını belirtmişlerdir (sırasıyla $28,6,19,7$ ve 17,6 ay). ${ }^{[9]}$ Santoni ve ark., kemik metastazı olan BHK hastalarını araştırdıkları çalışmalarında; yaş, Eastern Cooperative Oncology Group (ECOG) performans durumu, histoloji, Memorial Sloan Kettering Cancer Center (MSKCC) prognostik skoru, eşlik eden metastaz varlığı ve nefrektomi ile kemik metastazı arasındaki süreyi prognozla ilişkili olarak saptamışlar; ayrıca, nefrektomi ile kemik metastazı arasındaki sürenin beş yıldan fazla olduğu olgularda hayatta kalımın 22 ay, bir yıldan az olduğu olgularda ise 13 ay olduğunu bildirmişlerdir. ${ }^{[10]}$ Tablo 1 , kemiğin etkilenme durumuna göre hayatta kalım sürelerini göstermektedir. ${ }^{[11]}$ BHK'de iskelet sistemi metastaz mekanizması, meme kanserindeki ile aynıdır. Kemiğe tutunan tümör hücrelerinden salınan prostaglandinler, interlökin 6 (IL-6), aktive vitamin D, tümör nekroz faktör (TNF), paratiroid hormon (PTH) ve paratiroid hormon ilişkili protein (PTHrP) reseptör aktivatör nükleer faktör $\kappa B$ ligandı (RANKL) sistemi üzerinden osteoblastları ve stromal hücreleri aktive eder ve sonuç olarak osteoklast aktivasyonu gerçekleşir. Bu mekanizmalar üzerinden dönüştürücü büyüme faktörü-1 (TGF-1), epidermal büyüme faktör reseptörü (EGF-R), TGF- $\beta$ R reseptör inhibisyonu, kalsiyum düzeyini düşürücü tedaviler ve PTHrP inhibisyonu gibi yeni tedavi yöntemleri konusunda çalışmalar devam etmektedir. Metastatik BHK'de, çoklu metastazların tam olarak çıkarılması ile ile uzun hayatta kalım süreleri elde edilebilmektedir. Beş yıllık hayatta kalım metastatik hastalıkta \%10 iken, metastazlarının tam rezeksiyonu ile bu oran \% 40 'lara kadar yükselmektedir. ${ }^{[12]}$

\section{TANI}

Doğru ve erken tedavi için doğru tanı konulmalı, bunun için de yeterli bir öykü alınmalı, fizik muayene ve metastaz taramaları uygun şekilde yapılmalıdır. Ağrııı ya da şüpheli bölgelerin direkt radyografisi çekilmeli sorasında ise $B T$ ve manyetik rezonans (MR) görüntüleme istenmelidir. Metastatik bir lezyonda, kemikte mineral kaybı en az \%25 oranına ulaşmadan, lezyon direkt grafide görülemez. Direkt grafi, litik lezyonları, kırılmak üzere olan ya da kırılmış kemiği gösterir. Kemik sintigrafisi osteoblastik aktiviteye daha duyarlıdır. Fakat, litik lezyonlardaki kompansatuvar osteoblastik

Tablo 1. BHK'de median hayatta kalım süreleri

\begin{tabular}{lc}
\hline Durum & $\begin{array}{c}\text { Median } \\
\text { hayatta kalım süresi }\end{array}$ \\
\hline Kemik metastazı yok & 13,3 ay \\
Tanı anında kemik metastazı & $10,6-12$ ay \\
İzlemde kemik metastazı & 19,6 ay \\
İzlemde sadece kemik metastazı & 22,6 ay \\
İlk SRE bulgusu sonrası & 10 ay \\
\hline BHK, böbrek hücreli karsinom; SRE, iskelet ilişkili olaylar.
\end{tabular}


aktivite bir miktar tutulum gösterebilir. Buna rağmen, erken lezyonların kemik sintigrafisi ile saptanamayabileceği unutulmamalıdır. Bu nedenlerle, MR kemik metastazlarının tanısında en değerli yöntemlerden biridir. Pozitron-emisyon-tomografisi (PET) ve tüm vücut MR ise daha çok tanı ve tedavi takibinde kullanılır. Diğer tüm tanı yöntemleri uygulanmadan biyopsi yapılmamalıdır. Öncelikle, böbrekteki primer lezyondan girişimsel radyoloji eşliğinde biyopsi yapılır. Gerekli durumlarda, metastaz düşünülen kemik lezyonundan da biyopsi yapılır. Kemik metastazlarına yapılan iğne biyopsileri olguların \%90'ında tanı koydurur.

\section{TEDAVi}

Sinir basısı, kırık ve hiperkalsemi gibi bulguların önlenmesi, ağrının palyasyonu ve yaşam kalitesinin artırılması ana hedeftir. Medikal tedavi, tümör hücrelerinin RANKL sistemi üzerinden aktive ettikleri osteoklastların inhibisyonunu amaçlamaktadır ve genel olarak bisfosfonatlar ya da denosumab olmak üzere iki grup tedaviden oluşur.

\section{Bisfosfonatlar}

Bisfosfonatlar BHK'nin de içerisinde olduğu farklı tümörlere bağlı olarak gelişen SRE'yi hafifletmekte ve hastaların yaşam kalitesini artırmaktadır. ${ }^{[13]}$ SRE'nin hafifletilmesi amaciyla, klodronat, pamidronat, ibandronat ve zoledronik asit tanımlanmıştır. Bunlar arasında zoledronik asit en başarılı olanıdır ve metastatik meme kanseri, prostat kanseri, akciğer kanseri ve BHK'de osteoklast aktivitesini inhibe ederek SRE'yi hafifletmektedir. Ayrıca, zolendronik asitin tümör hücrelerini apoptozise uğrattığı in vitro olarak tespit edilmiştir. ${ }^{[14]}$ Everolimus bir mTOR inhibitörüdür ve hedefe yönelik tedavide kullanılır. Alcaraz ve ark., everolimusun tek başına ve zoledronik asit ile kombinasyonunu karşılaştırdıkları çalışmalarında, ilk SRE'nin ortaya çıkma süresini, sırasıyla 5,2 ve 9,6 ay olarak bildirmişlerdir. ${ }^{[15]}$ Görüldüğü üzere, hem klinik öncesi hem de klinik çalışmalar, bisfosfonatların BHK'de doğrudan anti-tümör etkileri olduğunu ve tümör ilerlemesini önlediğini göstermektedir. Bisfosfonatların grip benzeri yan etkileri olduğu ve BHK'de böbrek üzerine toksik etkileri olabileceği unutulmamalıdır. Diğer bir yan etki ise nadir görülen çene kemiği nekrozudur. Bu komplikasyonun, kombine tedavilerde daha sık görüldügüu belirtilmiştir. Bu nedenle, tedavi öncesinde ve sırasında diş hekimi muayenesi önerilir.

\section{Denosumab}

Denosumab, bisfosfonat tedavisinin işe yaramadığı ya da böbrek fonksiyonları açısından riskli olan metastatik kemik hastalığında, RANKL'ye bağlanarak kemik rezorpsiyonunu inhibe eden, insan monoklonal antikor grubuna ait bir moleküldür. Lipton ve ark., metastatik kemik hastalığında denosumab ve zoledronik asiti etki ve güvenilirlik açısından karşılaştırdıkları meta-analizde, denosumab tedavisi ile ilk SRE'nin görülme süresinin zoledronik asite oranla 8,21 ay daha geç olduğunu tespit etmişlerdir. Ayrıca, denosumabın monitörizasyona ihtiyaç duymaması, doz ayarlamasına gerek olmaması, renal fonksiyonları etkilememesi ve akut faz proteinlerini yükseltmemesi diğer avantajlardır. Osteonekroz oranları her iki ilaç grubunda benzer iken, hipokalsemi tablosu denosumab kullanımı ile daha sık gerçekleşmektedir. ${ }^{[16]}$ Bu nedenle tedaviye kalsiyum replasmanı eklenmesi önerilir.

\section{Diğer ilaçlar}

BHK, kemoterapi ve radyoterapiye dirençli bir tümördür. Sitokinlerin kemoterapötikler ile kombine edilmesi, maalesef önemli bir fark yaratmamıştır. Medroksiprogesteron ile \%5-6 oranında, IL-2 ve interferon-alfa (INF- $\alpha$ ) ile ise ancak \%7-27 oranında cevap elde edilebildiği raporlanmıştır. ${ }^{[17]}$ Bu nedenle, son yıllarda osteoklast aktivasyon mekanizmalarını hedef alan tedavi yöntemleri geliştirilmiştir.

\section{Hedefe Yönelik Tedavi}

Metastatik BHK'de hedefe yönelik tedavinin, sonuçları iyileştirdiği, tedaviye yanıt oranını artırdığı, hastalıksız ve genel hayatta kalımı uzattığı bildirilmektedir. ${ }^{[18]}$ Tümör progresyonu ile ilişkili biyolojik yolların anlaşılmaya başlanması ile, bu yolları hedef alan tedavi yöntemlerinde ilerleme sağlanmıştır. Bu ajanlar; sunitinib ve sorafenib gibi multikinaz inhibitörleri, bevacizumab gibi insan monoklonal antikor molekülleri ve everolimus ve temsirolimus gibi mTOR inhibitörleridir. Bunlar arasında sunitinib ve everolimus, daha iyi cevap oranları ve daha az toksisite ile BHK'de birinci basamak tedavi yöntemi olarak ortaya çıkmaktadır. Zolnierek ve ark., INF- $\alpha$, sunitinib ve sorafenib tedavilerini araştıran bir meta-analizde, sunitinibin diğer iki tedavi yöntemine oranla kemik metastazlarının ortaya çıkışı ve ilerlemesinde daha etkili olduğunu saptamışlardır. ${ }^{[19]}$

\section{Cerrahi Tedavi}

Metastatik olsa dahi, ağrı, hiperkalsemi, hipertansiyon ve eritrositozu azaltmak amacıyla BHK olgularına nefrektomi önerilmektedir. Seçilmiş hastalarda hedefe yönelik tedavilere ek olarak uygulanan nefrektominin, beklenen yaşam süresini altı ay kadar uzattığı ve nadiren de olsa metastazların gerilediği 
gösterilmiştir. ${ }^{[20]}$ Hedefe yönelik tedavilerin kullanılmasıyla birlikte, günümüzde adjuvan nefrektomi uygulaması daha az tercih edilmektedir.

BHK kemik metastazları, agresif kortikal destrüksiyona neden olan litik lezyonlardır. Bu lezyonlarda periost reaksiyonu görülmez. Omurga ve uzun kemikler gibi yük alan kemiklerde patolojik kırık riski yüksektir. BHK'de tekil metastaz nadirdir ve \%5'in altında bir oranda bildirilmiştir. ${ }^{[21]}$ BHK'ye bağlı izole bir kemik metastazında, radikal cerrahinin uzun dönemde olumlu etkilerinin olduğu bilinmektedir. Eğer hastada patolojik kırık yoksa ve tekil metastaz varsa, cerrahi sınırların temiz olduğu bir geniş rezeksiyon ile daha uzun hayatta kalım süreleri elde edilmektedir. ${ }^{[22]}$ Genel olarak, kırık beklentisi olan bir olguda beklenen yaşam süresi üç ayın altında ise cerrahi girişim önerilmemekte, 3-12 ay arasında ise daha az invaziv yöntemler, 12 aydan fazla ise de endoprotez yöntemleri önerilmektedir. ${ }^{[23]}$

BHK'ye bağlı kemik metastazlarının \%65'inden fazlası, primer tümör ile benzer şekilde hipervaskülerdir. ${ }^{[24]}$ Lezyonun boyutu ile ilişkili olarak, ameliyat öncesi dönemde konvansiyonel anjiyografi ya da BT anjiyografi gibi metotlarla, lezyonun ne derece hipervasküler olduğu saptanmalıdır. Aksi halde, ameliyat esnasında meydana gelebilecek aşırı kanama ameliyatın yapılmasını zorlaştırabileceği gibi hastanın hayatını da tehlikeye sokabilir. Pelvis, vertebra ve ekstremite yerleşimli büyük lezyon varlığında, bu durum özellikle ön plana çıkar. Hipervaskülarite ciddi boyutta ise ameliyattan önce mutlaka selektif embolizasyon yapılmalı, ciddi miktarda kan stoğu sağlanmalı ve anesteziye bilgi verilmelidir. Transkateter intra-arteriyel embolizasyon yöntemi ile kan kaybı ve transfüzyon ihtiyacının azaldığı bildirilmektedir. ${ }^{[25]}$

Hastaların çoğunda çoklu metastaz söz konusudur. Çoklu metastatik hastalık durumunda, ameliyat yapılacaksa da, geniş rezeksiyon yapılması zorunluluğu yoktur. Bu durumda amaç; hastayı ağrıdan kurtarmak, fonksiyon kazanmasını sağlamak ve tümör yükünden kurtarmaktır. Ameliyat sırasında, kitlenin mümkün olduğunca etrafından dolaşılarak büyük kısmı eksize edilmeli ve implantasyon yapılmalıdır. Hasta, bir an önce mobilize edilecek şekilde ameliyat edilmeli, implantasyon çok sağlam olmalıdır. Böyle bir operasyondan sonra, çoğu hastanın ağrılarında ciddi bir azalma olduğu ve fonksiyonların ciddi şekilde arttığı gözlenir. Ancak, beklenen hayat süresinde uzama olmayacaktır.

Cerrahi tedavi seçiminde Mirels kriterlerinden yararlanılabilir. ${ }^{[26]}$ Son yıllarda Nazarian ve ark., kırık tahmini ve tedavi planlamasında "BT tabanlı rijidite analizi" (CT-based Structural Rigidity Analysis -CTRA)
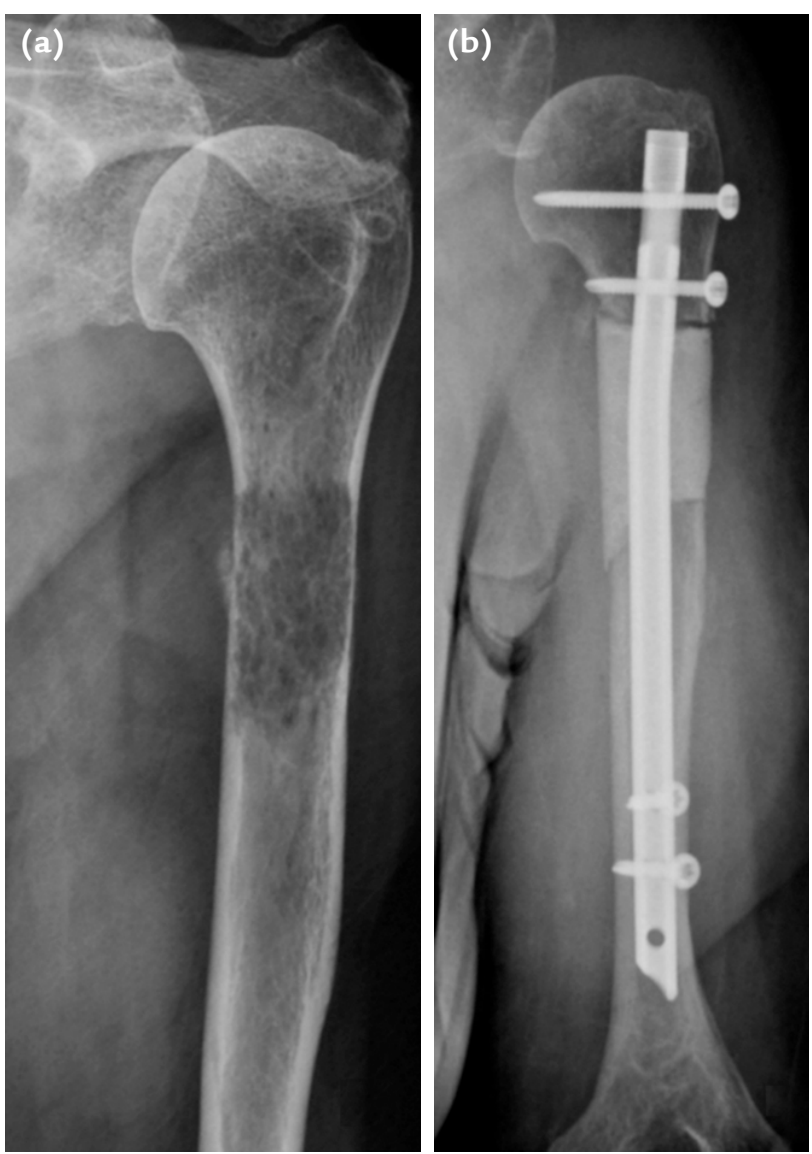

Şekil 1. a, b. Yetmiş üç yaşında kadın hasta. Sol humerus proksimal diyafizinde permeatif destrüksiyon dikkat çekiyor (a). Hastaya çimentolama ile beraber açık intramedüller çivi (IMN) yapılmış (b).

adıyla bir yöntem geliştirmişler ve bu yöntemin duyarlılık ve özgüllük oranlarının Mirels yönteminden yüksek olduğunu ifade etmişlerdir. ${ }^{[27]} \mathrm{Bu}$ rehberlere rağmen, tedavi seçimi yapılırken hastaya özel karar vermek gerekmektedir. Örneğin; genel durumu bozuk ve beklenen yaşam süresi çok kısa olgularda, yük taşımayan üst ekstremitenin izole kırıkları palyatif radyoterapi (RT), alçı ya da bandajlama ile tedavi edilebilir. Eğer hastada ek olarak alt ekstremite lezyonu da mevcutsa cerrahi tedavi düşünülmelidir. Cerrahi tedavi ve RT uygulanmadığı takdirde kemiğin kaynamasının neredeyse imkansız olduğu göz önünde bulundurulmalıdır. Ayrıca bu hastalar birden fazla girişimi kaldıramayacakları için cerrahi esnasında mutlak stabilizasyon sağlanmalıdır. Temel tedavi yöntemi kemik çimentosu ile kombine edilmiş internal tespit ya da protez uygulamasıdır (Şekil 1). Leggon ve ark., tedaviye çimentolama eklenmesi ile torsiyonel kuvvetlere karşı 2,6 kat daha fazla dayanıklılık elde edildiğini bildirmişlerdir. ${ }^{[28]}$ Tedaviye çimentolama eklenmesi stabiliteyi artırır, daha erken 

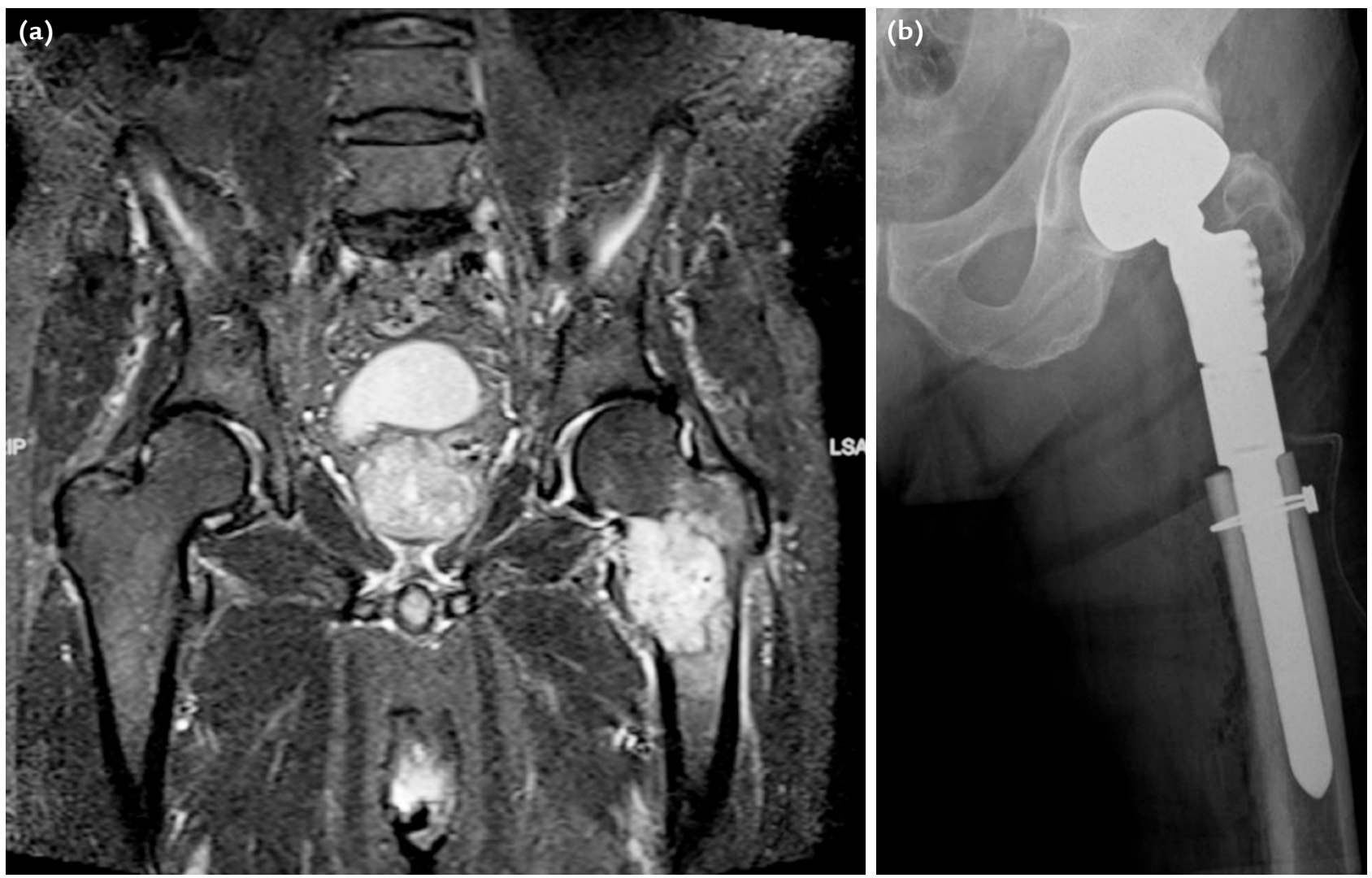

Şekil 2. a, b. Yetmiş sekiz yaşında erkek hasta. Sol femur üst ucunda kırık riski yaratan metastatik kitle mevcut (a). Hastaya tümör rezeksiyon protezi uygulanmış (b).
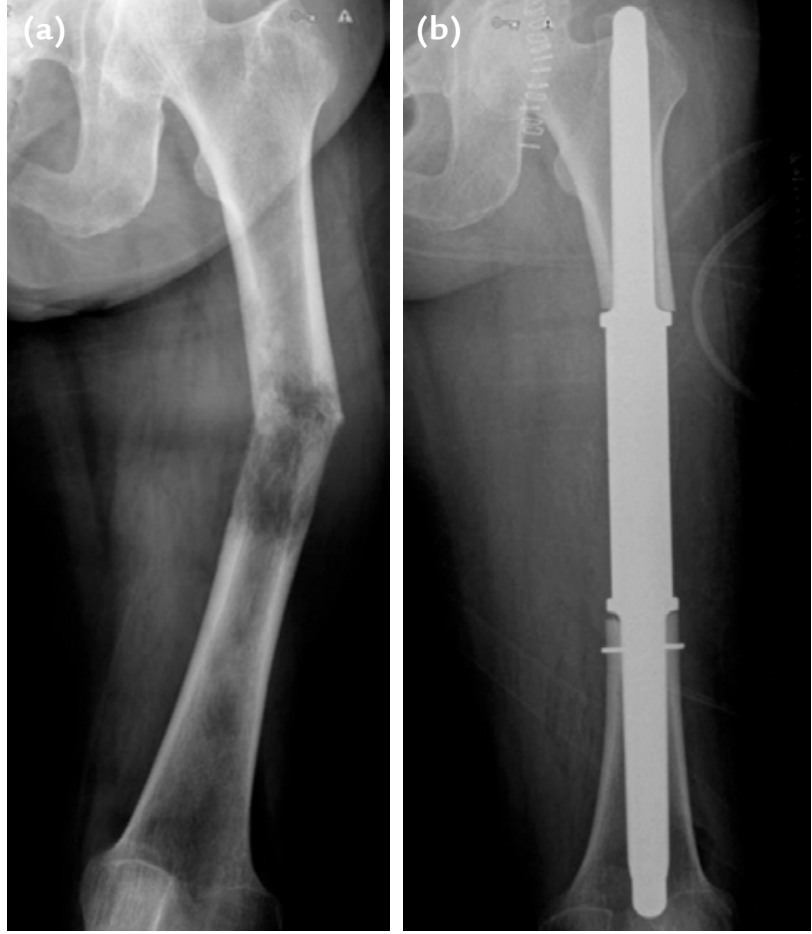

Şekil 3. a, b. Altmış beş yaşında kadın hasta. Sol femur orta diyafizinde patolojik kırık mevcut (a). Hastaya interkalar tümör protezi uygulanmış (b). hareket verilmesini sağlar, ağrıyı azaltır. Ayrıca, sementin lokal ısı etkisi ile canlı tümör hücrelerini nekroze ettiği ifade edilmektedir. Cerrahi tedavi kararı alınırken beklenen yaşam süresinin alt sınırı tartışmalıdır. Palyatif cerrahi tedavi için en az iki aylık yaşam beklentisinin olması gerektiği bildirilmiştir. ${ }^{[29]}$ Protez uygulanımı, ekleme yakın lezyon varlığında, proksimal femur, proksimal tibia, proksimal humerus ya da distal humerus gibi bölgelerde tercih edilmektedir (Şekil 2). Ayrıca uzun kemiklerin segmenter defektlerinde interkalar protezler kullanılabilmektedir (Şekil 3). Femur baş ve boynunu ilgilendiren, kırık beklentili lezyonlarda ve patolojik kırıklarda protez tercih edilmelidir. Damron ve ark., pelvis ve proksimal femur bölgesine uygulanan 298 protez, çivi ve plak olgusunu karşılaştırdıkları çalışmalarında iflas oranlarını sırasıyla \%3,1, $\% 6,1$ ve $\% 42$ olarak bildirmişlerdir. ${ }^{[30]}$ Burada karar verilirken, hastanın beklenen yaşam süresinin ameliyattan sonraki toparlanma süresinden uzun olması gerektiği akılda tutulmalıdır. Ayrıca, rekonstrüksiyon hemen yük vermeye izin verecek kadar sağlam olmalı ve kalan yaşam süresi boyunca da sağlamlığını sürdürebilmelidir. Genel olarak femur proksimalinde baş, boyun ve 
pertrokanterik lezyonlar kalkar destekli protezler ile subtrokanterik ve metafizer lezyonlar ise proksimal femur rezeksiyon protezleri ile tedavi edilir. ${ }^{[31]}$ Gerek protez, gerekse internal tespitte, gelecekte kırılma ihtimali olan bölgeleri de belirleyip yapılan tespite dahil etmek yararlı olacaktır. Örneğin hem femur proksimal metafizinde hem de distal diyafizinde kırık beklentisi olan eş zamanlı metastazlı bir hastada ya distale kadar uzanan uzun stemli bir rezeksiyon protezi kullanılmalı ya da proksimale rezeksiyon protezi uygulanarak distaldeki lezyona intralezyonel küretaj, çimentolama ve internal tespit yapılmalıdır.

\section{Radyoterapi}

BHK radyoterapiye dirençli olarak değerlendirilse de son yıllarda stereotaktik radyocerrahi ile yüksek doz radyasyon lokal olarak uygulanabilmekte ve lokal kontrol ve palyasyon sağlanabilmektedir. ${ }^{[32]}$ Ayrıca çoklu metastazları olan hastalarda RT ile kısa dönem ağıı kontrolü, kırıkların önlenmesi ve cerrahi ihtiyacının azaltılması mümkün olabilmektedir. ${ }^{[33]}$ Ameliyat edilemeyen ağrılı metastatik lezyonlarda; etanol, lazer, kriyoablasyon, mikrodalga ve radyofrekans ablasyon gibi minimal invaziv yöntemler de tanımlanmıştır. ${ }^{[34]}$ Son yıllarda perkütan girişimsel radyoloji eşliğinde yapılan osteoplasti ya da radyofrekans ablasyon yöntemleri, cerrahi tedaviye uygun olmayan hastalarda, RT'ye alternatif olarak, SRE bulgularını hafifletmede kullanılabilir.

Sonuç olarak; metastatik BHK insidansı, hedefe yönelik tedaviler sayesinde artmaktadır. Olguların \%85'inde SRE ve bağlı komplikasyonlar görülür. Bu semptomlar ekonomik yük oluşturmakta, yaşam kalitesini azaltmakta, morbidite ve mortalite oranlarını artırmaktadır. Metastatik BHK prognozu kötüdür ve primer lezyonun erken evrede saptanıp tedavi edilmesi önemlidir. Hastalığı tedavi edebilmek için ileri tedavi modaliteleri geliştirmek gerekmektedir. Bununla birlikte, tekil metastazlı bir BHK olgusunda primer tümörün ve tekil metastazın rezeksiyonunun daha uzun yaşam süresi sağlayabileceği unutulmamalıdır. Ayrıca, tekil metastaz rezeksiyonu, geniş lezyonlarda, progresif kemik destrüksiyonlarında, kırık beklentisinde, kontrol edilemeyen ağrı durumunda ve instabilite varlığında palyatif olarak da uygulanabilir.

\section{KAYNAKLAR}

1. FerlayJ, Soerjomataram I, Dikshit R, Eser S, Mathers C, Rebelo M, Parkin DM, Forman D, Bray F. Cancer incidence and mortality worldwide: sources, methods and major patterns in GLOBOCAN 2012. Int J Cancer 2015;136(5):E359-86. Crossref
2. Patard JJ, Rodriguez A, Rioux-Leclercq N, Guillé F, Lobel B. Prognostic significance of the mode of detection in renal tumours. BJU Int 2002;90(4):358-63. Crossref

3. McNichols DW, Segura JW, DeWeerd JH. Renal cell carcinoma: long-term survival and late recurrence. J Urol 1981;126(1):17-23. Crossref

4. Miyao N, Naito S, Ozono S, Shinohara N, Masumori N, Igarashi T, Nakao M, Tsushima T, Senga Y, Horie S, Kanayama HO, Tokuda N, Kobayashi M; Japanese Society of Renal Cancer. Late recurrence of renal cell carcinoma: retrospective and collaborative study of the Japanese Society of Renal Cancer. Urology 2011;77(2):379-84. Crossref

5. Kozlowski JM. Management of distant solitary recurrence in the patient with renal cancer. Contralateral kidney and other sites. Urol Clin North Am 1994;21(4):601-24.

6. Cohen HT, McGovern FJ. Renal-cell carcinoma. N Engl J Med 2005;353(23):2477-2490. Crossref

7. Motzer RJ, Bacik J, Mazumdar M. Prognostic factors for survival of patients with stage IV renal cell carcinoma: Memorial Sloan Kettering Cancer Center experience. Clin Cancer Res 2004;10(18 Pt 2):6302S-3S. Crossref

8. Woodward E, Jagdev S, McParland L, Clark K, Gregory W, Newsham A, Rogerson S, Hayward K, Selby P, Brown J. Skeletal complications and survival in renal cancer patients with bone metastases. Bone 2011;48(1):160-6. Crossref

9. Ruatta F, Derosa L, Escudier B, Colomba E, Guida A, Baciarello G, Loriot Y, Fizazi K, Albiges L. Prognosis of renal cell carcinoma with bone metastases: Experience from a large cancer centre. Eur J Cancer 2019;107:79-85. Crossref

10. Santoni M, Conti A, Procopio G, Porta C, Ibrahim T, Barni $S$, Guida F, Fontana A, Berruti A, Berardi R, Massari F, Vincenzi B, Ortega C, Ottaviani D, Carteni G, Lanzetta G, De Lisi D, Silvestris N, Satolli M, Collovà E, Russo A, Badalamenti G, Fedeli SL, Tanca F, Adamo V, Maiello E, Sabbatini R, Felici A, Cinieri S, Montironi R, Bracarda $S$, Tonini G, Cascinu S, Santini D. Bone metastases in patients with metastatic renal cell carcinoma: are they always associated with poor prognosis? J Exp Clin Cancer Res 2015;34(1):10. Crossref

11. Hofbauer LC, Khosla S, Dunstan CR, Lacey DL, Boyle WJ, Riggs $\mathrm{BL}$. The roles of osteoprotegerin and osteoprotegerin ligand in the paracrine regulation of bone resorption. J Bone Miner Res 2000;15(1):2-12. Crossref

12. Kato S, Murakami H, Takeuchi A, Demura S, Yoshioka K, Kawahara N, Tomita K, Tsuchiya H. Fifteen-year survivor of renal cell carcinoma after metastasectomies for multiple bone metastases. Orthopedics 2013;36(11):e1454-7. Crossref

13. Dhillon S, Lyseng-Williamson KA. Zoledronic acid: a review of its use in the management of bone metastases of malignancy. Drugs 2008;68(4):507-34. Crossref

14. Ullen A, Schwarz S, Lennartsson L, Kalkner KM, Sandstrom P, Costa F, Lennernas B, Linder S, Nilsson S. Zoledronic acid induces caspase-dependent apoptosis in renal cancer cell lines. Scand J Urol Nephrol 2009;43(2):98-103. Crossref

15. Alcaraz A, González-López R, Morote J, de la Piedra C, Meseguer C, Esteban E, Climent M, González-Gragera B, Alvarez-Ossorio JL, Chirivella I, Mellado B, Lara PC, Vázquez F, Contreras JA, Carles J, Murias A, Calderero V, CometBatlle J, González-Del Alba A, León-Mateos L, Mañas A, Segarra J, Lassa A, González-Enguita C, Méndez MJ, Samper P, Unda M, Mahillo-Fernández I, Bellmunt J; TUGAMO GROUP. Biochemical markers of bone turnover and clinical outcome in patients with renal cell and bladder carcinoma with bone metastases following treatment with zoledronic acid: The TUGAMO study. Br J Cancer 2013;109(1):12130. Crossref 
16. Lipton A, Fizazi K, Stopeck AT, Henry DH, Brown JE, Yardley DA, Richardson GE, Siena S, Maroto P, Clemens M, Bilynskyy B, Charu V, Beuzeboc P, Rader M, Viniegra M, Saad F, Ke C, Braun A, Jun S. Superiority of denosumab to zoledronic acid for prevention of skeletal-related events: a combined analysis of 3 pivotal, randomised, phase 3 trials. Eur J Cancer 2012;48(16):3082-92. Crossref

17. Coppin C, Porzsolt F, Kumpf J, Coldman A, Wilt T. Immunotherapy for advanced renal cell cancer. Cochrane Database Syst Rev 2000;(3): CD001425. Review. Update in: Cochrane Database Syst Rev 2005;(1):CD001425. Crossref

18. Keizman D, Ish-Shalom M, Maimon N, Gottfried M. Are bisphosphonates an indispensable tool in the era of targeted therapy for renal cell carcinoma and bone metastases? World J Urol 2014b;32(1):39-45. Crossref

19. Zołnierek J, Nurzynski P, Langiewicz P, Oborska S, WaskoGrabowska A, Kuszatal E, Obrocka B, Szczylik C. Efficacy of targeted therapy in patients with renal cell carcinoma with pre-existing or new bone metastases. J Cancer Res Clin Oncol 2010;136(3):371-8. Crossref

20. Giberti C, Oneto F, Martorana G, Rovida S, Carmignani G. Radical nephrectomy for renal cell carcinoma: long-term results and prognostic factors on a series of 328 cases. Eur Urol 1997;31(1):40-8.Crossref

21. Kavolius JP, Mastorakos DP, Pavlovich C, Russo P, Burt ME, Brady MS. Resection of metastatic renal cell carcinoma. J Clin Oncol 1998;16(6):2261-6. Crossref

22. Szendroi A, Dinya $E$, Kardos M, Szász AM, Németh $Z$, Ats K, Kiss J, Antal I, Romics I, Szendroi M. Prognostic factors and survival of renal clear cell carcinoma patients with bone metastases. Pathol Oncol Res 2010;16(1):29-38. Crossref

23. Forsberg JA, Eberhardt J, Boland PJ, Wedin R, Healey $\mathrm{JH}$. Estimating survival in patients with operable skeletal metastases: an application of a Bayesian belief network. PLoS One 2011;6(5):e19956. Crossref

24. Takahashi A, Sasaki H, Kim SJ, Tobisu K, Kakizoe T, Tsukamoto T, Kumamoto $Y$, Sugimura T, Terada M. Markedly increased amounts of messenger RNAs for vascular endothelial growth factor and placenta growth factor in renal cell carcinoma associated with angiogenesis. Cancer Res 1994;54(15):4233-7.
25. Chatziioannou AN, Johnson ME, Pneumaticos SG, Lawrence DD, Carrasco $\mathrm{CH}$. Preoperative embolization of bone metastases from renal cell carcinoma. Eur Radiol 2000;10(4):593-6. Crossref

26. Mirels $\mathrm{H}$. The Classic: Metastatic disease in long bones. A proposed scoring system for diagnosing impending pathologic fractures 1989. Clin Orthop Relat Res 2003;415 (Suppl):S4-13. Crossref

27. Nazarian A, Entezari V, Zurakowski D, Calderon N, Hipp JA, JC Camacho V, Lin PP, Cheung FH, Aboulafia AJ, Turcotte R, Anderson ME, Gebhardt MC, Cheng EY, Terek RM, Yaszemski M, Damron TA, Snyder BD. Treatment Planning and Fracture Prediction in Patients with Skeletal Metastasis with CT-Based Rigidity Analysis. Clin Cancer Res 2015;21(11):2514-2519. Crossref

28. Leggon RE, Lindsey RW, Panjabi MM. Strength reduction and the effects of treatment of long bones with diaphyseal defects involving 50\% of the cortex. J Orthop Res 1988;6(4):540-6. Crossref

29. Ward WG, Holsenbeck S, Dorey FJ, Spang J, Howe D. Metastatic disease of the femur: surgical treatment. Clin Orthop Relat Res 2003;(415 Suppl):S230-44. Crossref

30. Damron TA, Sim FH. Surgical treatment for metastatic disease of the pelvis and the proximal end of the femur. Instr Course Lect 2000;49:461-70.

31. Jacofsky DJ, Haidukewych GJ. Management of pathologic fractures of the proximal femur: state of the art. J Orthop Trauma 2004;18(7):459-69. Crossref

32. Yamada $\mathrm{Y}$, Bilsky MH, Lovelock DM, Venkatraman ES, Toner S, Johnson J, Zatcky J, Zelefsky MJ, Fuks Z. High-dose, singlefraction image-guided intensity-modulated radiotherapy for metastatic spinal lesions. Int J Radiat Oncol Biol Phys 2008;71(2):484-90. Crossref

33. Reichel LM, Pohar S, Heiner J, Buzaianu EM, Damron TA. Radiotherapy to bone has utility in multifocal metastatic renal carcinoma. Clin Orthop Relat Res 2007;459:133-8. Crossref

34. Gangi A, Kastler B, Klinkert A, Dietemann JL. Injection of alcohol into bone metastases under CT guidance. J Comput Assist Tomogr 1994;18(6):932-5. Crossref 